\title{
How Social Media Changes Today's Marketing Strategies
}

\author{
Nasr Abdulaziz Murshed \\ Doctor of Business Management Program, Istanbul Aydin University \\ Istanbul, Turkey
}

\begin{abstract}
In the past recent years, WhatsApp and WeChat have surprisingly fast growth. Facebook as well became the first social network to reach 1 billion active users every month. The presence of social media is an expectation for brands instead of an exception to the rule. Social events and shared information within your target market will help you understand developments in the industry. The opportunity to expose patterns in business in real time is a potential business intelligence goldmine. The worldwide rate of social penetration reached $49 \%$ in 2020 , with the highest penetration rates in East Asia and North America. Instagram enables users, through their standards of credibility, authenticity and transparency, to develop themselves. Influencers from social media have a personal recognizable identity, also known as the "true brand" An influencer has tools and values that can motivate many other followers to increase their presence in the media. Even if these leads do not directly buy via social, awareness-raising can lead them to become full-time buyers. The overwhelming majority of users in Instagram are under the age of $\mathbf{3 0}$ according to recent Social Media demographics. Marketers face a dilemma: more and more people want businesses to take a social stand, but $\mathbf{7 9 \%}$ of CMOs fear that their capacity to attract consumers will be adversely affected. Businesses can mitigate negative emotions by providing positive information to popular social media users. Marketing managers will encourage consumers through tournament and influencer programmers to engage in contact practices so customers can evangelize and encourage their loyalty to the organization through the creation and delivery of user-generated content.
\end{abstract}

Keywords:- Social Media , Social Media Influencers, Social Media Firestorm, Social Media Advantages.

\section{INTRODUCTION}

The Internet has become the most important part of everyone's life right now, we are connected in a way that we never thought possible and that affects every aspect of our personal life as well as our businesses.

There is no doubt that social media platforms are at the heart of today's use of the Internet, shape how people communicate and define their ideas and perspectives on almost everything. That's why any business owner, depositing how big it is, needs to understand how this trend is going and how he can make use of such tools.
In this article, we will try to look at some of the most important social media new topics, such as social media influencers, social media endorsement and native advertising, as well as social media conflicts, so-called social media firestorms.

At the end, we will summarize some of the advantages that can be derived from social media in order to benefit marketing on the basis of our professional experience supported by up to date resources.

\section{LITERATURE REVIEW}

\section{A. The rise of social media era}

keyways people communicated a while ago through the media were public services including television, radio and newspaper, so someone with this kind of media would be just a viewer because they cannot react to the broadcasters [1]. Those channels don't have any real effect on who makes up its audience ideas but may inspire people to join them [2].

For instance, a telephone chat was often referred to as 'dyadic.' People could meet face to face, but group-based media contact such as the telephone was rare. This division between public and private media began to shift with the growth of the Internet. As for now, you can give a group an e-mail in one click [3]

The wider industry, as well as other online media such como CB Radio, is covered through message boards, niche forums, Chat rooms and blogging. Nevertheless, much of the daily media communication was regulated by public and private broadcasting [4] .

The early development of social networking sites was basically a scaling down of public media, so that people in groups could become communities' individuals. In such groups, usually there were just a few hundred participants [5].

Indeed, the people who built these communities connect by commenting on the remarks of other people. The rise of text messages and internet networks such as MSM and AOL took place at about the same time[6] .

With the initiation of the cell phone, in particular the BlackBerry Messenger (BBM), BlackBerry's proprietary messaging platform, this technology was significantly underrated in the past even though, it was 
a precursor to WhatsApp. Such apps took private messages and put them up with various features from the crowd [7].

In the past recent years, this trend was reinforced and channels such as WhatsApp and WeChat have surprisingly fast growth. As the users tend to build smaller and more intimate groups, typically around 20 people or less. And that's not the way which Facebook and Twitter arrange their users' interactions [8] .

In general, everybody in social media has equal rights and can post whatever, whenever they want, as opposed to the networks of just one person. These are societies. They are particularly important as such written contact has carried more and more young people's voice over the Internet [9] .

There is a broad variety of avenues of social networking, including blogging, forums, business networks, photo sharing, social platforms, microblogs, messaging apps and eventually news networks. The worldwide rate of social penetration reached $49 \%$ in 2020, with the highest penetration rates in East Asia and North America at $71 \%$ and $69 \%$ in Europe, followed by northern Europe at $67 \%$ [10].

According to Clement [11], the social networking impact is increasing significantly as by 2023 about a third of the population of the planet, around 3,43 billion, would be active social media users per month. About 800 million of these consumers will come from China alone and almost 450 million from India in 2023.

Leading social networks typically have huge user profiles or strong indicators for special user experience. For example, Facebook is the first social network to reach 1 billion active users every month. As of the first quarter of 2020, 2,6 billion MAU was achieved worldwide. The web is now considered as one of the world's most popular social networks [11].

Instagram, which is a photo sharing platform, is among major social networks, which has more than one billion active users monthly and, most recently, 500 million daily ordinary users with its Stories feature. Both Facebook Messenger and WeChat are popular social platforms for web users, along with messaging applications such as WhatsApp [12] .

Given the pervasive existence of the social network, the number of users, as well as user interest continue to grow, continues to increase. In average, digital web users stay in social networks for 144 minutes a day[13].

In order to promote a variety of products and services through social media; viral advertising allows global brands or their marketers to use those channels and reach much more targeted customers[14].

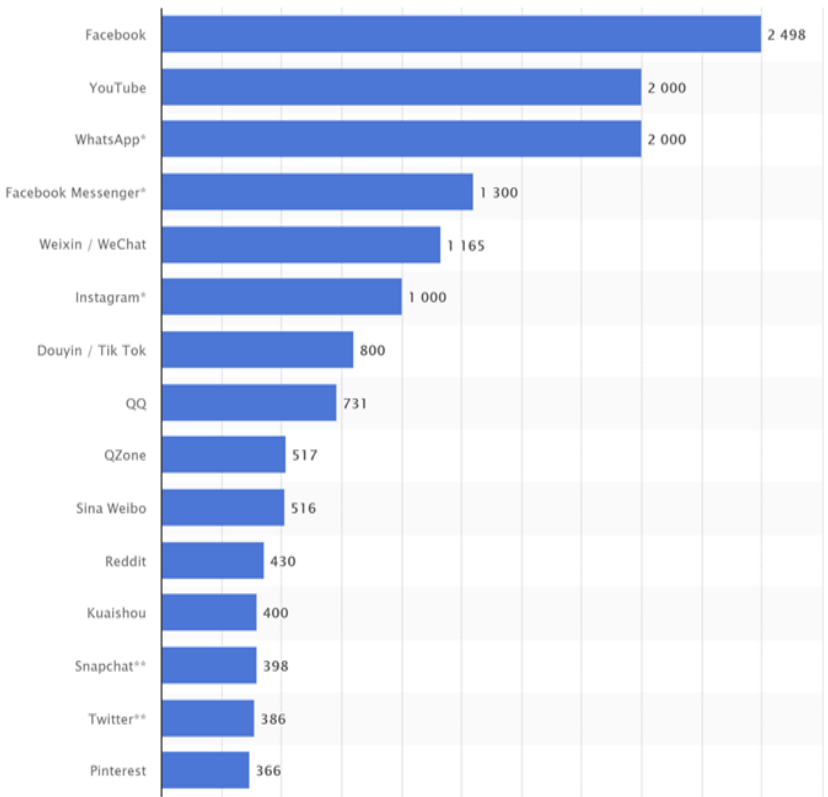

Fig 1:- The world's largest social platforms; As of April 2020

Measured by number (in millions) of active users * In the last 12 months, platforms have not released updated user data, data may not be obsolete and accurate ** The MAU data and data use from publication by third parties are not shared on these networks. Source: (Clement, 2020)

User profiles count or a high degree of user engagement are usually present in the most popular social networks. Facebook, the market leader, became the first social network to have over 1 billion active daily users and Pinterest the new pioneer to cross 10 million unique monthly users. Pinterest has become an independent website. Many of the social networks have been established in the USA with more than a hundred million users, but the famous appeals in their regions have also developed in European sites such as VK or Renren's social networks[15].

The user's social network is broad and varied: sites like Facebook concentrate heavily on friendly and family connections and actively encourage communication with apps such as picture sharing or status sharing and video gaming. Many social networks are community-based; others highlight content created by users and share it [16].

Social networks have a surprisingly high social influence due to their daily presence in the lives of their users. Some of the topics that have emerged in past debates are the blurring of offline and virtual reality, and that is the definition of digital identity and online social networking[17]. 


\section{B. Social platforms overview in the last decade}

Media seemed so much simpler a decade ago. All of our newsfeeds have not been sponsored ads. Nobody was also an influencer in social media. It was best left to professional photo editing, and even live streaming in an app wasn't something we can dream of.

Over the last decade, social media has grown enormously from keeping in contact with others to flaunting up what we must pay attention or curate unacknowledged representations of our true selves.

We moved from drainage to a constant sea of memes, and digitally poked our friends on Facebook. The influence of social media has undermined political elections and changed our way of communicating while constantly raising issues about privacy.

It is safe to tell that social media will not lift us anytime soon after more than a decade of scrolling, thumb taping, sliding and dual tapping. Less than 1 billion people were signed in 2010. This has since tripled, with Facebook remaining the market leader since Myspace was detrimental with its 1 billion users. Below is a look back at sites that helped define the decade of social networking.

\section{> Facebook}

The wall was one of the main functions defined by Facebook in 2010. You went there to leave your friend with a thoughtful message or a joke. CEO Mark Zuckerberg killed him a year later, when Timeline was introduced. There have been many other big redesigns in the social networking giant ever since. It introduced new ways of showcasing current events and news and was more group-centric recently. The decade was characterized mainly by controversies about the security of privacy, and Facebook was well known to have spread so-called "fake news" [11].

\section{Twitter}

Twitter was first started in 2006 as microblogging website only, then Twitter launched an official mobile application on iOS and Android in 2010. In the early days, the 140-specific and restrictive messages existed. Over the years, the platform has changed its interface, so it is possible to share videos and photographs on the mobile phone, and the word 'tweet' was added to the Oxford English dictionary in 2013, which makes it a popular app[13].

\section{Tumblr}

Tumblr started creating its own internet corner in 2007 and soon grew into one of the most frequently visited websites in the United States. It started as a short blogging website that builds memories and brings together people with niche interests. With the $\$ 1.1$ billion deal, Yahoo acquired Tumblr in 2013. In a year after its founder, David Karp and then President Barack Obama spoke of pronouncing the word GIF as one of his most prominent moments. After the ban of all adult content at the end of 2019, Tumblr remains a skin of its former self. The left users flooded to Twitter. Tumblr sold earlier this year to the blogger's WordPress site creator [12].

$>$ Vine

In 2012, the six-second video messaging app produced waves by introducing the world to short, redoubling video content. The time limit became an innovative job for users, and Twitter acquired it for $\$ 30$ million shortly afterwards. Vine was innovative, benefitting from a preference for short and fun videos on smartphones. What did Twitter for status updates for video? Vine did for video: keep it short. After Vine uploaded a video to the picture sharing app, Instagram was the beginning of the end of Vine success[18].

\section{Instagram}

The app was just 2 years old when Facebook shelled out 1 billion dollars to buy Instagram in 2012, and the app design was so easy. People can create third-party photo collages, smash a powerful sunburn filter on them and post it in three clicks. The app provided iPhone 4 users back then with a new photosharing platform and in the first three months, it hit 1 million downloads. Since then Instagram has soared over 1 billion users monthly. Practically all famous people are there. Influencers have developed careers to do as all others do, but better, and users continue to publish clean photos of themselves carefully [19].

\section{$>$ Snapchat}

For young adults, Snapchat was a game changing app which allowed them to post contents that soon vanished. In about 2010 Stanford University met the creators of its photo messaging app and launched an app called Picaboo, later Snapchat. Despite a number of privacy concerns, the app hit 1 million daily active users in 2012. And the "My Story" function was invented in 2013 and became "Stories" later. Snapchat's stories soon later adapted by of Facebook and Instagram. however Snap hit 100 million everyday users [20].

\section{TikTok}

In China in 2016, the app was mainly for young people, formerly called Musical.ly, soon after it reached 1 billion marks for worldwide installations in 2019. The mobile app is used to create amateur music videos, and incorporates songs that other social networking do not allowed normally. While TikTok still in its early stages, the app could guide social media 's future. As of November, TikTok reached 1.5 billion Apple App and Google Play downloads [21].

\section{$>$ Zoom}

Recently, Zoom hit the headlines for an increasing number of security and privacy concerns, but that doesn't seem to have stopped people from flocking into the video conference app. Zoom has now announced that it has reached 300 million daily participants to the 
Zoom conference. That's up 50 per cent from the company's 200 million reported earlier this month, and a huge jump back in December from the 10 million [11].

Zoom does state the numbers are members of regular meetings, which will count five times the same person if they attend five Zoom meetings in one day. Nevertheless, Zoom claims it has "more than 300 million active users" and that "more than 300 million people around the world use Zoom during this difficult period." That assertion was later clarified on April 29, saying the use of "users" and "people" was a mistake.

Either way, given the security and privacy issues that have been posed recently, more people are using Zoom. Zoom has introduced a 90-day freeze of functionality, and later the company launches Zoom 5.0 to fix some of the complaints. Zoom 5.0 contains default passwords, improved encryption and a new security icon for meeting access.

Zoom growth continues unabated as more people turn to the service in order to stay connected during the ongoing coronavirus pandemic. In incorporating Zoompowered video calls, even British politicians have now broken traditions from 700 years of practice in the House of Parliament and had a video conference over zoom [11].

\section{Other platforms}

According to the market research company Statista (2020), Reddit, Pinterest and LinkedIn have approximately 300 million active users worldwide. Throughout the last decade, these apps have evaporated large privacy scandals and front-page coverage. In January 2020 Pinterest will celebrate its 10-year anniversary. LinkedIn started slowly in the early 2000s and was a regular source of expertise for job seekers, employers and recruits. And Reddit 's website for discussion is still doing what Facebook should; bring together people [22].

\section{CASE STUDY AND FINDINGS}

\section{A. Social media Influencers}

For the purpose of this article we use the theoretical and practical literature to identify social media influents as individuals with broad online follow-up who receive a lot of exposure (e.g. like) and are willing to use this popularity for brands. Influencers from social media have a personal recognizable identity, also known as the "true brand"[23].

An influencer has tools and values that can consistently motivate many other followers to increase their presence in the media. Thus, social media fans are not limited to themselves. They can connect with their followers who post their posts and exponentially enhance their growth[24].
It is interesting from a theoretical and practical point of view to know what certain people have many names as 'influencers' who often are named 'instafamous,' 'micro-famous,' 'company mav' and the 'common king' to name a few [25] .

Influencers vary in how they achieve fame from traditional celebrities in order to label themselves as personal brands or celebrities. Traditional celebrities gain success through excellence, music, sport, politics and develop their work, their image and their public relations credibility [26].

Meanwhile, influencers establish their personal image through the media [27]. Platforms such as Instagram enables users, through their standards of credibility, authenticity and transparency to develop themselves and improve their chance for success, and even get them world class endorser [28].

This is the result of the close ties between fans and influencers, who have online source of revenue. There is an increasing debate about what constitutes enough followers / favors or acceptable level of followers / who want to be included as power in social media [29].

It leaves no understanding of how much people participate or what types of influencers in social media from various cultures like. Lin et al. [30] Moreover claim that the leading positions of different influencers are special online and that they differ on the basis that influencers (i.e. the number of followers and the attention they attract) are media portrays.

There is also a major gap in literature in the effect of various influencers on customer experience. While academic literature does not provide a straightforward and accurate analysis of the many supporters, industry reports provide some clarity [31] .

Social media influencers have different classifications. Porteous [32], for example, suggests three levels: micro, macro and popular, while others suggest two levels, micro and macro [32]. The two-tier classification appears to be the most widely used and debated, both in academia and practice.

Canning [33] argues that the measurement by the number of followers who influence social media players is easily modified to depend on the number of similar influencers who they receive and the percentage of support posts that they earn (the share of those who love them).

Furthermore, this commitment rate can be a better indicator of an impact on a company's future interest if the commitment is buying steps. Literature also endorses the use of likes as a measure of the strength of interaction based on the number of likes [34]. 
In reality, researchers and experts are now claiming that the number of ' likes ' is often indicative of the scale of influencer followership and is called the 'like Follower Ratio,' which Kim \& Xu [35] believe that social media users have favorable views on the content based on 'like quantity'. Research have also shown that consumers anticipate a higher number of shares of media trust[36].

In addition, research has shown that the "heart" in connection with a certain message has more effect, as the peer group's acceptance of that message has shown [37].

In turn, we use 'Likes' to differentiate between various types of social media influencers, which are indicative of the monitoring of social media influencers and that 'Likes' are extremely (persuasive) influence in user responses[38].

\section{B. Revelation of support / sponsorship for native ads}

Native publicities, also known as sponsored content identify any paid advertising publication that has the same form and distribution of publishing material[39].

Another big aspect of natives' advertisements is the inclusion of non-sponsored content, such as social media messages, blogs, reviews, images, and articles, alongside and sometimes intermingled with the material on the same web platform[40].

This phenomenon leads to the combination of native media and its contextual climate, rendering the distinction between advertising and non-advertising material difficult for consumers to distinguish[18].

For example, influencers in social media share personal posts to their profiles and sponsored posts. The extent of this intermingling of funded and unsponsored content has been found by Campbell and Grimm[18] most apparent among social media influencers.

The possible risk of harm to the user in this setting is greater, because it is difficult to differentiate between advertising by manipulating media and wordof - mouth, entertainment or editorial content [41].

Advertisement becomes more common with social media influence goals, and regulators and decision makers are also beginning to criticize because it is misleading[18].

Consequently, legal and legislative changes require influencers in the social media to report their support to their followers. Despite these reforms, the impact of native social media advertising is increased as funded posts are expected to be disclosed[40].
The importance of announcement for supporting is related to two sources of research. The first case centered on the straightforward use of broadcast advertising in traditional market environments. The second source deals with openness and in particular the role that social media influencers play in native advertising environments[42] .

As influencer marketing is a recent phenomenon, work on publicity disclosure in this field is little or no obligatory in most cases. The resounding literature consensus, however, is that accepting advertising results in negative brand impressions and a decline in the ability to take part in an online speech-of-themouth approach [42].

For instance, research carried out by Boerman et al . [43] found that disclosure led to a lower brand role, whereas Wojdynski and Evans [39] found that disclosure would have an adverse impact on both attitudes and behavioral intentions; however, it is largely unknown what impact disclosure would have on influence and especially on various influencer levels.

Nonetheless, there was no systematic research on openness and the level of social media influencers and their impact on consumer awareness [44].

Considering the lack of research on the impact of social media in this area, it is important to learn how openness affects the interactions of consumers and whether the findings are consistent with previous investigations or complexities.

Audrezet et al.[45] notice the need for more work in this field is supported by more stringent disclosure regulations. Of the limited number of studies in this field, disclosure is also important for influencers of social media.

There are therefore data indicating that endorsement transparency is important, and further investigation is needed to provide more insight into recent policy changes and guidelines promoting and facilitating the reporting of content-sponsored customer assessments by social media influencers [46].

\section{Social media Firestorms}

Contemporary marketing analyzes address many issues and problems in the social media environment related to branding. A social media firestorm, described as a sudden release of large numbers of messages that include derogatory feedback and protesting activity against an individual, organization or community on social media networks, is one of the most drastic threats for companies [47].

In general, research into social media and online scandals suggests that brand equity is being undermined and companies should take steps to quench it. Thus, managers are advised to respond rapidly, 
maintain good ties with consumers by supportive media attention and take steps to address contested issues[19].

Experts in crisis management point out that the appeasement of brand criticism is not necessary or desirable. It is particularly true in online criticism, which arises from perceptions that these moral principles have been violated by an organization [30].

Such rational social media storms are especially relevant from a branding perspective, although undertheoretical, consumer phenomena. Moral misdemeanor accusations cause $61 \%$ of the company's storm[48].

However, moral concerns have a smaller effect on public perceptions than corporate storms that are triggered by other concerns, likely because a small minority overpowers a vast majority of people not sharing the same views motivates the debate[49].

Ethical issues are still the foundation for many company storms that lead to deliberate brand-marketing decisions, which have been so aptly demonstrated by the recent media uproar at Gillette, Nike and Pepsi. Marketers thus face a dilemma: more and more people want businesses to take a social stand, but 79 per cent of CMOs fear that their capacity to attract consumers will be adversely affected[50].

Sociological media storms are dynamic phenomena which can be triggered by a variety of incidents, include many actors and require that companies determine the capacity of various response strategies [51].

According to Wojdynski et al.[40] previous studies, these subjects were usually identified and isolated, but the relationship between them seldom investigated. Some multidisciplinary studies have influenced the effectiveness of various response strategies for different stakeholders, but they did not discuss how violations of moral principles can, as triggers, affect the viability of corporate response strategies or how brand companies can open up consumer interaction during corporate storms [45].

Although many incidents can lead to social media protests, the expectations of customers that a business violates certain moral values are one of the most significant factors[52].

Researchers study Internet corporate press reports notice that $61 \%$ of corporate target storms have come from claims of suspected moral misconduct by firestorm [53].

Most humanely, relational anxiety and the need to preserve societal norms have shown that consumers are more likely to engage in organizational chaos [52].
Previous researches using predictive analysis techniques has shown that businesses can mitigate negative emotions during firestorm by providing positive information to popular social media users and immediately defending the organization by having a large number of moderators[54] .

Such studies demonstrate the importance of hiring supportive voices during a firestorm, but they actually assume the company is sponsored by influential consumers or corporate leaders. Given the discrepancies between the shape, number and response times of the protection forces but not how the target brand responds effectively to their opponents [55] .

Markets studies also showed how people follow immense moral principles that lead to ongoing differences among different moral camps. Therefore, when claims of immoral behaviour are the trigger of social outcry, the tendency of companies to base on their opinions rather than the facts and characterized by emotional exchanges is likely to be exacerbated[56].

In short, prior work on marketing has made moral social media storms a major advertising phenomenon, but the shades that occur in these moral events have not yet been studied in detail. Some research has shown that businesses are well-advised to seek more assertive responses, particularly where brand supporters can protect their brand[57].

For example, customers can be encouraged to be more loyal to the organization through the creation and delivery of user-generated content that contributes to the business narrative[51]

Branding literature basically gives insights into how managers can facilitate brand narratives by cocreating different online and offline activities that encourage and structure consumer participation. Marketing managers will encourage consumers through tournament and influencer programmers to engage in contact practices [58].

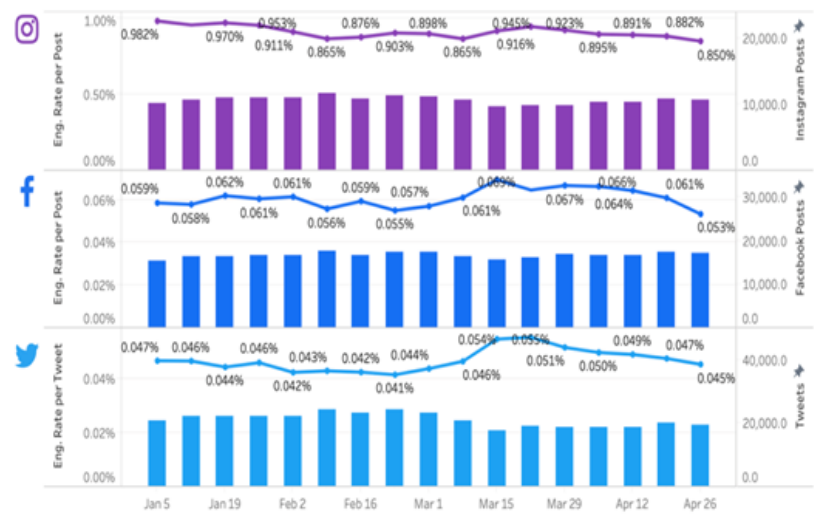

Fig 2:- Median Engagement rate per Post (by follower) Week by week from Jan. 5th to May. 2nd 2020 Source: (FEEHAN, 2020) 
Brands may also have broader market visibility and publicity through acknowledgment and reorganizations of consumer narrative contributions in addition to the financial or material encouragements. Therefore, brand managers can co-create stories by describing events that inspire customers to communicate with each other[59] .

Brand managers should also coordinate the narrative process for co-creation, distribution and hosting online media spaces where stories are created and shared[60] .

They should create and enforce guidelines for submitting consumer content during competition, supplying consumers with brand-generated images, and promoting hashtags that illustrate history framing, and their own [61].

For both cases, the involvement of the company makes it possible to shape and guide the development of stories and forms by identifying technological resources and offering guiding principles[62].

\section{COVID-19 impact on Social media}

During this pandemic, we 're all adapting to life, whether it's marketing at a time when people buy less, work from home or study home. If we test the engagement in social media after three full months of coronavirus.

As seen from figure 2 below, the lowest engagement rate was on Instagram and Facebook in 2020, and almost on Twitter. Since the end of March, the downward trend on all three channels has been slow and steady .Posting in February hit a high point and in mid-March fell to its lowest when coronavirus actually caught up in steam in America. Post frequency has marginally climbed back, but is floating on all three channels around 2020 [63].

Instagram, like Facebook and Twitter, experiences its lowest 2020 engagement, and since the beginning of coronaviruses, these numbers have gradually decreased. Besides Higher Ed, most industries are part of the lowest Instagram engagement of the year. The higher Ed maintains their participation rates around their median for 2020, but what happens when the school is out for the summer will be interesting. Hotels \& Resorts are among the few industries that improved their Q2 engagement rates compared to their first quarter performance.It looks like the participation levels of the Sports Teams are eventually dropping and are now rebounding. The retail was very flat, with no coronaviral spikes or dips[11].

Since early March, Facebook engagement rates have fallen sharply, though they slipped back a bit in early May before dropping off again at the end of the month. Despite a fall following its initial increase in April, alcohol has managed to adhere to higher levels of commitment. Financial Services and Higher Ed, which saw massive rises in coronavirus at the peak, are seeing Facebook's lower rates in 2020. Hotels and resorts and influencers have experienced epic highs and lows before preparing for summer back to medium 2020 engagement. Just like on Instagram, sports teams seem to have returned last month on Facebook after reaching the rock bottom[11].

The engagement rates on Twitter have gradually decreased for the whole of Q2. Curiously, the frequency of postings has not bounced back as it has on Facebook and Instagram. The financial services and Higher Ed were unable to cope with the pandemic. The brands of Health \& Beauty have recently fallen on Twitter following some major spikes earlier this year. Hotels \& Resorts are now seeing a substantial increase in commitment and have managed in Q2 to sustain a slightly higher commitment rate than in Q1. Throughout the year, media and technology have surprisingly flat engagement rates.

Post COVID-19, digital marketing would allow companies and brands to rethink their game plan and establish ongoing projects within the core practices of paid publicity. In order to prepare for reopening and relaunching stages, digital marketing departments will change their media preparation and campaign schedules as soon as possible. In future promotions, the focus needs to be to improve the importance of life and consumer life, and to offer a positive brand.

Right now, it's a confusing and frightening time for both brands and consumers and no one is the right way to do things in society. "It will be very unpredictable how consumers spend their time online over the next couple of months. Although it will increase the total time that is spent online, it will be difficult for most marks to compete with news, entertainment and services.

The best thing marketers can do to create social media posts and strategy is to be as sensitive as possible to the current health crisis. While also look for data and comparisons to make the social activities across the globe meaningful rather than deviate.

\section{DISCUSSION AND THEORETICAL IMPLICATIONS}

Now more than ever, social media deserve your attention. While it does not instantly contribute to a cash flow or a "viral" moment that you expect, they help your brand and business in more than the social aspect as so much can be done in short and long term for your company. Here is the rundown of the advantages that modern businesses frequently receive under the radar of social media. 


\section{$>$ The opportunity to expose trends in business in real time}

The openness in social media is a potential corporate intelligence goldmine. As we can see both customers and companies in unfiltered, real-time conversations. If you want to know what a company is doing well or what consumers talk about, everything is out there[64].

And your social interaction and shared material of the target market will of course help you to understand the developments in the industry. For example, Instagram hashtags will illustrate anything ranging from major influencers to current trends in fashion [65].

\section{$>$ Comprehensive analysis of the competition}

The opportunity to spy on the rivals can be one of the biggest social media marketing advantages. what are they targeting now? Which kind of publicity do they run? How is it different from your marketing strategy? There must be no question marks for these responses[66].

You may find ways to push in new directions in terms of content or ads by doing a social media competitive study. You may know, for example, that your rivals smash Facebook ads, but they lack their Instagram presence. In turn, for the sake of excellence in Instagram, you could explore marketing influencers or content created by users[20].

\section{$>$ Enhance customer service}

About half of all users have already accessed social networks to answer questions and concerns. In comparison, social customer services are fast and ondemand, in comparison to challenging phone calls or long emails. Providing social customer service includes constructive, forward-looking interactions with your customers[21].

Prospectively, consumers and rivals can see how the consumers communicate. Positive front-and-center interactions are a major advantage for any company. Whether you listen to feedback or answer particular issues, the constant advantage of social media is that it offers a quick service and lends customers a helping hand. Social media is also a key channel for gathering feedback from customers[63].

\section{Take a snap to build customer content and stories}

The images and success stories of customers correlate with the increased engagement and conversion rates. And the social media is no better place to gather them. Monitoring your information and tags, for example, can help you discover positive interactions with customers [67].

As many leading brands and retailers regularly curate photos for customers during their marketing campaigns. That's why it is so important to have a branded hashtag. You will detect shareable posts that your supporters would enjoy when interacting with your customers by enabling your customers to tag their contents[68].

\section{Place your competitive strength}

This may seem like a brainless thought, but it should be listed. It just means the company is placed by providing an active presence on a social forum. Publishing your brand is involved and opened to new customers on platforms that are important for your enterprise [69].

Don't ignore the social media's absolute positioning power in search engines. Your first impression on a customer in relation to your products and services may be in your Twitter or Instagram. And that's why it is important to keep an active present in all social media platforms with a consistent message of strength for your band[70].

\section{$>$ Establish ties and boost the presence of the search engine}

For years, the social media SEO effect has been heatedly discussed and, thus, the fairly recent notion of unbundled links suggests that social media and search success are associated. In short, shares and social clicks are good signals for Google's search. If nothing else, social traffic can be a significant source as through Google Analytics, you can track your social traffic (Campbell \& Evans, 2018).

Should not ignore social media as a distribution platform for content. A popular content that scores hundreds of likes and shares can drive your site through serious reference traffic [22].

\section{Appeal to young, socially savvy clients}

The ultimate understatement would be to say that social media transformed the traditional publicity landscape. The concept of the media as a trendy may seem quite cliché, particularly because it can attract people of all ages. This is also possible for young advertising channels [71].

Nonetheless, research shows that Gen $\mathrm{Z}$ responds less and less to mainstream advertising and shakes up marketing. As younger customers grow with social media, brands must adapt over advertising and advertising. Instagram for example is where younger customers can be reached not the old newspaper[72] .

\section{$>$ Consider your brand alive}

Corporations want to display their human side rightly today. Too many companies have benefitted from the "costume and tie" environment. MoonPie is an example of a snark social presence which looks like it is run by a teenager. It is one of the most common examples. Although this kind of social approach is not for every company, it certainly is not what most consumers expect and thus drives commitment. 


\section{$>$ Further leads at top-of-the-funnel}

Finally, the leading, quick and fast, is one of the main benefits of social media marketing. Since billions of people are already involved in social media, your audience is not impossible to be there. Whether you're using paid ads or promotional content, you can increase awareness of your brand in further cutting-edge leads [73].

$77 \%$ of Pinterest users discover new brand and buy them from what they see on the website. Another way to boost sales is by creating a social presence that attracts customers to what you sell [62].

\section{CONCLUSION}

It would not be an exaggeration to say that the majority of people spend a large portion of their days on social media. Not in the real world.

Social media has become an integral part of the daily routines of people's lives. Some are so addicted to it that their first thing to do when they wake up is to update their social media feeds.

Bearing in mind the role of social media in the lives of consumers, advertisers and companies rush to social networks in the hope of communicating with their target clients. However, social media is overloaded with content, and the competition is very high. Unless you have a clear strategy for social media marketing it can be extremely difficult for you to stand out.

Too many companies are moving ad-hoc into social media marketing. They know they ought to do something about social media but don't really understand what they ought to do. Some companies only give some junior staff members access to the company's social pages-just because they 're young, and they should know all about social media.

But we're well past a post-and-hope social approach. All businesses need to develop a marketing plan for social media and run the social business accounts in a deliberate, calculated manner. If you don't, you risk the danger of your competitors gaining market traction and exposure over you, and as a result.

Nonetheless, businesses cannot avoid social media. As 71 per cent of customers who have had a positive experience with a brand in social media service are likely to recommend it to others. Yet 96 percent of people debating brands online do not follow the proprietary profiles of those brands.

Even if you embrace the wonders of influencer marketing, you still have some social accounts to operate on your own. Influencer marketing also has the goal of attracting visitors to your social media. Influencer marketing should be considered merely an extension of the social marketing strategy for your company.

\section{REFERENCES}

[1]. S. Khamis, L. Ang, and R. Welling, "Self-branding, 'micro-celebrity' and the rise of Social Media Influencers," Celebr. Stud., vol. 8, no. 2, pp. 191-208, 2017, doi: 10.1080/19392397.2016.1218292.

[2]. B. Gleason, "Thinking in hashtags: exploring teenagers' new literacies practices on twitter," Learn. Media Technol., vol. 43, no. 2, pp. 165-180, 2018, doi: 10.1080/17439884.2018.1462207.

[3]. C. Lou and S. Yuan, "Influencer Marketing: How Message Value and Credibility Affect Consumer Trust of Branded Content on Social Media," $J$. Interact. Advert., vol. 19, no. 1, pp. 58-73, 2019, doi: 10.1080/15252019.2018.1533501.

[4]. M. Johnen, M. Jungblut, and M. Ziegele, "The digital outcry: What incites participation behavior in an online firestorm?," New Media Soc., vol. 20, no. 9, pp. 3140-3160, 2018, doi: 10.1177/1461444817741883.

[5]. P. A. Rauschnabel, N. Kammerlander, and B. S. Ivens, "Collaborative Brand Attacks in Social Media: Exploring the Antecedents, Characteristics, and Consequences of a New Form of Brand Crises," $J$. Mark. Theory Pract., vol. 24, no. 4, pp. 381-410, 2016, doi: 10.1080/10696679.2016.1205452.

[6]. T. Aleti, J. I. Pallant, A. Tuan, and T. van Laer, "Tweeting with the Stars: Automated Text Analysis of the Effect of Celebrity Social Media Communications on Consumer Word of Mouth," J. Interact. Mark., vol. 48, pp. 17-32, 2019, doi: 10.1016/j.intmar.2019.03.003.

[7]. P. Ikonen, V. Luoma-aho, and S. A. Bowen, "Transparency for Sponsored Content: Analysing Codes of Ethics in Public Relations, Marketing, Advertising and Journalism," Int. J. Strateg. Commun., vol. 11, no. 2, pp. 165-178, 2017, doi: 10.1080/1553118X.2016.1252917.

[8]. S. De Jans, V. Cauberghe, and L. Hudders, "How an Advertising Disclosure Alerts Young Adolescents to Sponsored Vlogs: The Moderating Role of a PeerBased Advertising Literacy Intervention through an Informational Vlog," J. Advert., vol. 47, no. 4, pp. 309-325, 2018, doi: 10.1080/00913367.2018.1539363.

[9]. A. Martensen, S. Brockenhuus-Schack, and A. L. Zahid, "How citizen influencers persuade their followers," J. Fash. Mark. Manag., vol. 22, no. 3, pp. 335-353, 2018, doi: 10.1108/JFMM-09-2017-0095.

[10]. S. V. Jin, A. Muqaddam, and E. Ryu, "Instafamous and social media influencer marketing," Mark. Intell. Plan., vol. 37, no. 5, pp. 567-579, 2019, doi: 10.1108/MIP-09-2018-0375.

[11]. J. Clement, "Social media - Statistics \& Facts," statista, 2020. https://www.statista.com/topics/1164/social-networks/ (accessed May 18, 2020). 
[12]. A. P. Schouten, L. Janssen, and M. Verspaget, "Celebrity vs. Influencer endorsements in advertising: the role of identification, credibility, and ProductEndorser fit," Int. J. Advert., vol. 39, no. 2, pp. 258281, 2020, doi: 10.1080/02650487.2019.1634898.

[13]. J. Kees and J. C. Andrews, "Research Issues and Needs at the Intersection of Advertising and Public Policy," J. Advert., vol. 48, no. 1, pp. 126-135, 2019, doi: 10.1080/00913367.2019.1599747.

[14]. S. Mills, A. Patterson, and L. Quinn, "Fabricating celebrity brands via scandalous narrative: crafting, capering and commodifying the comedian, Russell Brand," J. Mark. Manag., vol. 31, no. 5-6, pp. 599615, 2015, doi: 10.1080/0267257X.2015.1005116.

[15]. P. M. Podsakoff, S. B. MacKenzie, J.-Y. Lee, and N. P. Podsakoff, "Common Method Biases in Behavioral Research: A Critical Review of the Literature and Recommended Remedies," J. Appl. Psychol., vol. 88, no. 5, pp. 879-903, 2003, doi: 10.1037/00219010.88.5.879.

[16]. X. Zhao, M. Zhan, and C.-W. Wong, "Segmenting and understanding publics in a social media information sharing network: An interactional and dynamic approach," Int. J. Strateg. Commun., vol. 12, no. $1, \quad$ pp. 25-45, 2018, doi: 10.1080/1553118X.2017.1379013.

[17]. M. Pedroni, "Meso-celebrities, fashion and the media: How digital influencers struggle for visibility," Film. Fash. Consum., vol. 5, no. 1, pp. 103-121, Jan. 2017, doi: 10.1386/ffc.5.1.103_1.

[18]. C. Campbell and P. E. Grimm, "The Challenges Native Advertising Poses: Exploring Potential Federal Trade Commission Responses and Identifying Research Needs," J. Public Policy Mark., vol. 38, no. 1, pp. 110-123, 2019, doi: $10.1177 / 0743915618818576$.

[19]. S. Kusumasondjaja and F. Tjiptono, "Endorsement and visual complexity in food advertising on Instagram," Internet Res., vol. 29, no. 4, pp. 659-687, 2019, doi: 10.1108/IntR-11-2017-0459.

[20]. C. Stubb and J. Colliander, "'This is not sponsored content' - The effects of impartiality disclosure and ecommerce landing pages on consumer responses to social media influencer posts," Comput. Human Behav., vol. 98, pp. 210-222, 2019, doi: 10.1016/j.chb.2019.04.024.

[21]. L. T. V. Nguyen, V. N. Lu, S. R. Hill, and J. Conduit, "The mediating role of brand knowledge on employees' brand citizenship behaviour: Does organizational tenure matter?," Australas. Mark. J., vol. 27, no. 3, pp. 169-178, 2019, doi: 10.1016/j.ausmj.2019.04.003.

[22]. M. Moraes, J. Gountas, S. Gountas, and P. Sharma, "Celebrity influences on consumer decision making: new insights and research directions," J. Mark. Manag., vol. 35, no. 13-14, pp. 1159-1192, 2019, doi: 10.1080/0267257X.2019.1632373.

[23]. K. Rost, L. Stahel, and B. S. Frey, "Digital Social Norm Enforcement: Online Firestorms in Social Media," PLoS One, vol. 11, no. 6, 2016, doi: 10.1371/journal.pone.0155923.
[24]. N. Hansen, A.-K. Kupfer, and T. Hennig-Thurau, "Brand crises in the digital age: The short- and longterm effects of social media firestorms on consumers and brands," Int. J. Res. Mark., vol. 35, no. 4, pp. 557-574, 2018, doi: 10.1016/j.ijresmar.2018.08.001.

[25]. F. Hauser, J. Hautz, K. Hutter, and J. Füller, "Firestorms: Modeling conflict diffusion and management strategies in online communities," $J$. Strateg. Inf. Syst., vol. 26, no. 4, pp. 285-321, 2017, doi: $10.1016 /$ j.jsis.2017.01.002.

[26]. G. McCracken, "Who is the Celebrity Endorser? Cultural Foundations of the Endorsement Process," $J$. Consum. Res., vol. 16, no. 3, p. 310, Dec. 1989, doi: 10.1086/209217.

[27]. M. De Veirman, V. Cauberghe, and L. Hudders, "Marketing through instagram influencers: The impact of number of followers and product divergence on brand attitude," Int. J. Advert., vol. 36, no. 5, pp. 798-828, 2017 , doi: 10.1080/02650487.2017.1348035.

[28]. M. B. Goodman, N. Booth, and J. A. Matic, "Mapping and leveraging influencers in social media to shape corporate brand perceptions," Corp. Commun. An Int. $J$. , vol. 16, no. 3, pp. 184-191, 2011, doi: $10.1108 / 13563281111156853$.

[29]. E. Djafarova and C. Rushworth, "Exploring the credibility of online celebrities' Instagram profiles in influencing the purchase decisions of young female users," Comput. Human Behav., vol. 68, pp. 1-7, 2017, doi: 10.1016/j.chb.2016.11.009.

[30]. H.-C. Lin, P. F. Bruning, and H. Swarna, "Using online opinion leaders to promote the hedonic and utilitarian value of products and services," Bus. Horiz., vol. 61, no. 3, pp. 431-442, 2018, doi: 10.1016/j.bushor.2018.01.010.

[31]. J. S. Lim, "How a paracrisis situation is instigated by an online firestorm and visual mockery: Testing a paracrisis development model," Comput. Human Behav., vol. 67, pp. 252-263, 2017, doi: 10.1016/j.chb.2016.10.032.

[32]. J. Porteous, "Micro Influencers vs Macro Influencers, What's Best for Your Business? | Socialbakers." https://www.socialbakers.com/blog/micro-influencersvs-macro-influencers (accessed Sep. 10, 2020).

[33]. N. Canning, "Instagram Analytics: Ultimate Guide to Posts, Stories, IGTV \& more!" https://later.com/blog/instagram-analytics/ (accessed Sep. 10, 2020).

[34]. S. Hong and G. T. Cameron, "Will comments change your opinion? The persuasion effects of online comments and heuristic cues in crisis communication," J. Contingencies Cris. Manag., vol. 26, no. 1, pp. 173-182, 2018, doi: 10.1111/14685973.12215.

[35]. H. Kim and H. Xu, "Exploring the effects of social media features on the publics' responses to decreased usage CSR messages," Corp. Commun., vol. 24, no. 2, pp. 287-302, 2019, doi: 10.1108/CCIJ-10-2017-0095.

[36]. J. Matthes and B. Naderer, "Product placement disclosures: Exploring the moderating effect of placement frequency on brand responses via 
persuasion knowledge," Int. J. Advert., vol. 35, no. 2, pp. 185-199, 2016, doi: 10.1080/02650487.2015.1071947.

[37]. S. M. Reich, K. Subrahmanyam, and G. Espinoza, "Friending, IMing, and hanging out face-to-face: Overlap in adolescents' online and offline social networks," Dev. Psychol., vol. 48, no. 2, pp. 356-368, 2012, doi: 10.1037/a0026980.

[38]. A. M. Elbedweihy, C. Jayawardhena, M. H. Elsharnouby, and T. H. Elsharnouby, "Customer relationship building: The role of brand attractiveness and consumer-brand identification," J. Bus. Res., vol. 69, no. 8, pp. 2901-2910, 2016, doi: 10.1016/j.jbusres.2015.12.059.

[39]. B. W. Wojdynski and N. J. Evans, "Going Native: Effects of Disclosure Position and Language on the Recognition and Evaluation of Online Native Advertising," J. Advert., vol. 45, no. 2, pp. 157-168, 2016, doi: 10.1080/00913367.2015.1115380.

[40]. B. W. Wojdynski, N. J. Evans, and M. G. Hoy, "Measuring Sponsorship Transparency in the Age of Native Advertising," J. Consum. Aff., vol. 52, no. 1, pp. 115-137, 2018, doi: 10.1111/joca.12144.

[41]. J. Singh and B. Crisafulli, "Managing online service recovery: procedures, justice and customer satisfaction," J. Serv. Theory Pract., vol. 26, no. 6, pp. 764-787, 2016, doi: 10.1108/JSTP-01-2015-0013.

[42]. S. C. Boerman, L. M. Willemsen, and E. P. Van Der Aa, "'This Post Is Sponsored': Effects of Sponsorship Disclosure on Persuasion Knowledge and Electronic Word of Mouth in the Context of Facebook," $J$. Interact. Mark., vol. 38, pp. 82-92, 2017, doi: 10.1016/j.intmar.2016.12.002.

[43]. S. C. Boerman, E. A. van Reijmersdal, and P. C. Neijens, "Sponsorship Disclosure: Effects of Duration on Persuasion Knowledge and Brand Responses," J. Commun., vol. 62, no. 6, pp. 1047-1064, 2012, doi: 10.1111/j.1460-2466.2012.01677.x.

[44]. D. Holt, "Branding in the age of social media," Harv. Bus. Rev., vol. 2016, no. March, 2016.

[45]. A. Audrezet, G. de Kerviler, and J. Guidry Moulard, "Authenticity under threat: When social media influencers need to go beyond self-presentation," $J$. Bus. Res., vol. 117, pp. 557-569, 2020, doi: 10.1016/j.jbusres.2018.07.008.

[46]. J. Ilicic and C. M. Webster, "Being True to Oneself: Investigating Celebrity Brand Authenticity," Psychol. Mark., vol. 33, no. 6, pp. 410-420, 2016, doi: 10.1002/mar.20887.

[47]. Y. Xiong, Z. Cheng, E. Liang, and Y. Wu, "Accumulation mechanism of opinion leaders' social interaction ties in virtual communities: Empirical evidence from China," Comput. Human Behav., vol. 82, pp. 81-93, 2018, doi: 10.1016/j.chb.2018.01.005.

[48]. L. V. Casaló, C. Flavián, and S. Ibáñez-Sánchez, "Influencers on Instagram: Antecedents and consequences of opinion leadership," J. Bus. Res., vol. 117, pp. 510-519, 2020, doi: 10.1016/j.jbusres.2018.07.005.
[49]. B. Harms, T. H. A. Bijmolt, and J. C. Hoekstra, "Digital Native Advertising: Practitioner Perspectives and a Research Agenda," J. Interact. Advert., vol. 17, no. 2, pp. 80-91, Jul. 2017, doi: 10.1080/15252019.2017.1357513.

[50]. S. C. Boerman, E. A. van Reijmersdal, and P. C. Neijens, "Effects of sponsorship disclosure timing on the processing of sponsored content: A study on the effectiveness of european disclosure regulations," Psychol. Mark., vol. 31, no. 3, pp. 214-224, 2014, doi: 10.1002/mar.20688.

[51]. R. V. Kozinets, K. De Valck, A. C. Wojnicki, and S. J. S. Wilner, "Networked narratives: Understanding word-of-mouth marketing in online communities," $J$. Mark., vol. 74, no. 2, pp. 71-89, 2010, doi: 10.1509/jmkg.74.2.71.

[52]. J. Ge and U. Gretzel, "Emoji rhetoric: a social media influencer perspective," J. Mark. Manag., vol. 34, no. 15-16, pp. 1272-1295, 2018, doi: 10.1080/0267257X.2018.1483960.

[53]. Y. Hwang and S.-H. Jeong, “"This is a sponsored blog post, but all opinions are my own': The effects of sponsorship disclosure on responses to sponsored blog posts," Comput. Human Behav., vol. 62, pp. 528-535, 2016, doi: 10.1016/j.chb.2016.04.026.

[54]. A. M. Kaplan and M. Haenlein, "Two hearts in threequarter time: How to waltz the social media/viral marketing dance," Bus. Horiz., vol. 54, no. 3, pp. 253263, 2011, doi: 10.1016/j.bushor.2011.01.006.

[55]. D. Kuksov, R. Shachar, and K. Wang, "Advertising and consumers' communications," Mark. Sci., vol. 32, no. 2, pp. 294-309, Nov. 2013, doi: 10.1287/mksc. 1120.0753 .

[56]. R. V. Kozinets, Netnography and the digital consumer: The quest for cultural insights. 2013.

[57]. A. I. Canhoto and Y. Padmanabhan, "'We (don't) know how you feel' - a comparative study of automated vs. manual analysis of social media conversations," J. Mark. Manag., vol. 31, no. 9, pp. 1141-1157, 2015, doi: 10.1080/0267257X.2015.1047466.

[58]. L. I. Labrecque, E. Markos, and G. R. Milne, "Online Personal Branding: Processes, Challenges, and Implications," J. Interact. Mark., vol. 25, no. 1, pp. 37-50, 2011, doi: 10.1016/j.intmar.2010.09.002.

[59]. C. Amos, G. Holmes, and D. Strutton, "Exploring the relationship between celebrity endorser effects and advertising effectiveness: A quantitative synthesis of effect size," Int. J. Advert., vol. 27, no. 2, pp. 209234, 2008, doi: 10.1080/02650487.2008.11073052.

[60]. L. Austin, B. F. Liu, and Y. Jin, "How Audiences Seek Out Crisis Information: Exploring the SocialMediated Crisis Communication Model," J. Appl. Commun. Res., vol. 40, no. 2, pp. 188-207, 2012, doi: 10.1080/00909882.2012.654498.

[61]. M. C. Campbell, G. S. Mohr, and P. W. J. Verlegh, "Can disclosures lead consumers to resist covert persuasion? The important roles of disclosure timing and type of response," J. Consum. Psychol., vol. 23, no. 4, pp. 483-495, 2013, doi: 10.1016/j.jcps.2012.10.012. 
[62]. J. Kang, A. Manthiou, N. Sumarjan, and L. Tang, “An Investigation of Brand Experience on Brand Attachment, Knowledge, and Trust in the Lodging Industry," J. Hosp. Mark. Manag., vol. 26, no. 1, pp. 1-22, 2017, doi: 10.1080/19368623.2016.1172534.

[63]. F. WALLACE, "The Impact of Coronavirus on Social Media Engagement for Brands | Rival IQ." https://www.rivaliq.com/blog/coronavirus-on-socialmedia-engagement-for-brands/ (accessed Sep. 10, 2020).

[64]. Y. Grégoire, A. Salle, and T. M. Tripp, "Managing social media crises with your customers: The good, the bad, and the ugly," Bus. Horiz., vol. 58, no. 2, pp. 173-182, 2015, doi: 10.1016/j.bushor.2014.11.001.

[65]. E. Reid and K. Duffy, "A netnographic sensibility: developing the netnographic/social listening boundaries," J. Mark. Manag., vol. 34, no. 3-4, pp. 263-286, 2018, doi: 10.1080/0267257X.2018.1450282.

[66]. Y.-Q. Zhu and H.-G. Chen, "Social media and human need satisfaction: Implications for social media marketing," Bus. Horiz., vol. 58, no. 3, pp. 335-345, 2015, doi: 10.1016/j.bushor.2015.01.006.

[67]. S. Roh, "Examining the paracrisis online: The effects of message source, response strategies and social vigilantism on public responses," Public Relat. Rev., vol. 43, no. 3, pp. 587-596, 2017, doi: 10.1016/j.pubrev.2017.03.004.

[68]. S. Pace, B. Balboni, and G. Gistri, "The effects of social media on brand attitude and WOM during a brand crisis: Evidences from the Barilla case," $J$. Mark. Commun., vol. 23, no. 2, pp. 135-148, 2017, doi: $10.1080 / 13527266.2014 .966478$.

[69]. C. C. Childers, L. L. Lemon, and M. G. Hoy, "\#Sponsored \#Ad: Agency Perspective on Influencer Marketing Campaigns," J. Curr. Issues Res. Advert., vol. 40, no. 3, pp. 258-274, 2019, doi: 10.1080/10641734.2018.1521113.

[70]. S. Leroi-Werelds, S. Streukens, Y. Van Vaerenbergh, and C. Grönroos, "Does communicating the customer's resource integrating role improve or diminish value proposition effectiveness?," J. Serv. Manag., vol. 28, no. 4, pp. 618-639, 2017, doi: 10.1108/JOSM-11-2015-0366.

[71]. C. Hughes, V. Swaminathan, and G. Brooks, "Driving Brand Engagement Through Online Social Influencers: An Empirical Investigation of Sponsored Blogging Campaigns," J. Mark., vol. 83, no. 5, pp. 78-96, 2019, doi: 10.1177/0022242919854374.

[72]. D. Scarpi, G. Pizzi, and F. Raggiotto, "The extraordinary attraction of being ordinary: A moderated mediation model of purchase for prototypical products," J. Retail. Consum. Serv., vol. 49, pp. 267-278, 2019, doi: 10.1016/j.jretconser.2019.03.006.

[73]. Y. Cheng, "How Social Media Is Changing Crisis Communication Strategies: Evidence from the Updated Literature," J. Contingencies Cris. Manag., vol. 26, no. 1, pp. 58-68, 2018, doi: 10.1111/14685973.12130 . 